\title{
Biological control of root knot nematodes in chillies through Pseudomonas fluorescens's antagonistic mechanism
}

\author{
Samaraj Subramanian Thiyagarajan ${ }^{1,2,3,}$, Hari Kuppusamy ${ }^{1}$ \\ ${ }^{1}$ R\&D, Hartley Biocontrol, Coimbatore, 641045, TamilNadu, India \\ ${ }^{2}$ University of Texas at San Antanio, D Current institution Thermo Fischer Scientific \\ ${ }^{3}$ Sugarcane Breeding Institue, Coimbatore, 641007, TamilNadu, India
}

Email address:

atsamraj@yahoo.com (S. S. Thiyagarajan), sbi_hari@hotmail.com (K. Hari)

\section{To cite this article:}

Samaraj Subramanian Thiyagarajan, Hari Kuppusamy. Biological Control of Root Knot Nematodes in Chillies through Pseudomonas fluorescens's Antagonistic Mechanism. Journal of Plant Sciences. Vol. 2, No. 5, 2014, pp. 152-158. doi: 10.11648/j.jps.20140205.12

\begin{abstract}
Among many pests and diseases, nematodes are one of the most important pests. Managing nematode chemically is very expensive. The damage caused by this pest results in considerable economical loss for the agriculture community. The important factor for increased pest management expenses, and decreased return on investment is due to inefficiency of chemical nematicides to provide a prolonged pest resistance. Chilli (Capsicum annum) is an important crop in India and is cultivated throughout India. Nematodes are an important pest for chillies. Primary nematode species infesting chili plants are the Root knot nematode Meloidogyne Incognita. In this study, susceptible variety PKM-1 developed by Tamil Nadu Agriculture University was used. Nematode control through biopesticides Pseudomonas fluorescence was assessed. Pseudomonas fluorescences's antagonistic activity was studied to understand the efficiency and duration of its antagonistic activity. Pseudomonas fluorescens's nematode resistance was compared with chemical and untreated plants. In summary, the study concludes that Pseudomonas fluorescens comparatively was more effective in sustained control of nematodes than chemical treatments.
\end{abstract}

Keywords: Pseudomonas Fluorescens, Root Knot Nematode, Carbofuran. Chilli Capsicum Annum

\section{Introduction}

Root-Knot caused by nematode in vegetable crop is a serious problem in India and all over the world. Crops are affected both quantitatively and qualitatively. Among the pests that infest commercial crops, Root-knot nematode Meloidogyne sp is the most prevalent pest. Eleven species of this nematode have been reported from different states of India. (Sitaramaiah,1984). Diverse effects of the pesticide approach and inefficiency of the chemicals to control nematode lead to search for alternative methods. Identifying and developing integrated pest and disease management had given the growers a relief to reduce the nematode population in crop fields. (Nusbaum and Ferris 1973).

Chille (Capsicum annum) is an important commercial crop and is grown worldwide for its edible fruits; it is a rich source of protein, and essential minerals. This crop is crucial for the industrial economy as it is used in food processing and other commercial industries. United Nations (FAO, 2003). Dried chillies are often ground into powders; they are also made into paste. Coloring industry uses it as raw material. Hence it has a more commercial interest for both farmers and industrial stakeholders. Any disruptions to its cultivation wills have a ripple effect on the upstream markets.

Root knot nematode causes damage for several crops like chilli, tomato, potato. Meloidogyne species are the most prominent family affecting vegetable crops. (Williamson VM and Hussey RS et al, 1996). They initiate a series of changes in the root, resulting in the formation of galls, commonly called as root knots. Nematodes are often identified as sedentary endo-parasites, but they need to be mobile to reach the root system (Bird AF, 1961). Once the nematodes are at the root it, then pierces the hard tissues by using a biochemical process to gain entry into the vascular system (Giebel J, 1974).

Chilli crops infested with this nematode appears to be stunted in growth, low flowering, and low yield. Chemical 
control proved to be ineffective and expensive. Integrated pest management approach, including biological approach and nutrient enrichment will provide a long term solution. (Sosamma VK, and Koshy PK, 1997). Pseudomonas fluorescens had been identified as a viable Biocontrol agent for controlling many plant diseases (Schroth MN and Hancock, 1982, Samaraj ST and Hari K, 2014). Farmers are increasingly using the bacterial agent to control soil borne pathogens (Duffy BK, and Defago G, 1997). Several studies in other crops have been proven to be effective. In this research, the biocontrol effect on nematode control in the chilli crop was studied.

\section{Materials and Methods}

\subsection{Pseudomonas Fluorescens Culture Preparation}

Pseudomonas fluorescens culture developed internally from the strain PF1 (agar slants) obtained from Tamil Nadu Agriculture University. The strain was mass multiplied using king's B broth media Nandakumar R et al, (2001). The cultures were grown using PPE bottles. Cultures were incubated at room temperature for 72 hours. Cultures were harvested and their concentration was at $10^{6} \mathrm{cfu} / \mathrm{ml}$. The broth was added to the talc for making the talc based formulation. (Vidhyasekaran and Muthamilan, 1995). $10 \mathrm{~kg}$ of talc powder processed with adjusting $\mathrm{pH}$ to neutral by adding $\mathrm{CaCO} 3$ at the rate of $10 \mathrm{~g} / \mathrm{kg}$. CMC was added to talc and mixed well. The mixture was autoclaved for $30 \mathrm{~min}$ each, twice on two consecutive days. $600 \mathrm{ml}$ of bacterial suspension containing $6 \times 10^{9} \mathrm{cfu} / \mathrm{ml}$ was mixed with carriercellulose mixture under aseptic conditions. The powder mixture was then dried overnight. Once its moisture was approximately $35 \%$, it was stored in an in polypropylene room temperature. Prior to application, the bacterial count was at $4 \times 10^{6} \mathrm{cfu} / \mathrm{g}$ of talc powder.

\subsection{Experimental Designs}

The field trials were conducted at Pertholuvzhu, Coimbatore district (Field $A$ ). The second trial was conducted at the Sukkanputhur, Erode district (Field B). PKM 1 variety released by Tamil Nadu Agriculture University was used. The nursery was raised and the seedlings were transplanted after the field was ploughed and leveled. Plots were separated into three different blocks. Each plot was at $30 \mathrm{~m} \mathrm{X} 20 \mathrm{~m}$ in dimensions. Ridges and furrows were formed at a spacing of $60 \mathrm{~cm} .40$ days old seedlings were transplanted. Seedlings were transplanted at $60 \times 45 \mathrm{~cm}$ spacing. Weed control was done through hand weeding.

\subsection{Nematode Extraction and Counting}

Soil sample was collected, and nematode presences in the soil per 10 cubic inches were calculated using the decanting and sieving method. Soil samples were mixed, sieved through coarse sieve to remove rocks and other debris. Soil samples were then mixed with water and stirred a few times before changing sieves. The samples were then sieved with
60 mesh, and again sieved in 325 mesh after stirring. Soil remaining in the 325 mesh sieve was further washed and counted after staining and observing under microscope (Barker KR, 1985). The count resulted in 63 per sq inch of the soil.

The Pseudomonas florescence talc formulation was mixed at the rate of $50 \mathrm{gm} / \mathrm{kg}$ of soil and the mixture was applied around the transplanted plants. The plot was designated as biocontrol treated. In the second plot, chemical Carbofuran was added at the rate of $10 \mathrm{gm}$ per plant. The plot was designated as chemical treated plot. Third plot was designated as control and was not treated with anything.

Ten plants from each plot were harvested after 100 days and 160 days. Following parameters were evaluated: Each plant was measured for the Plant shoot height, root height, both these measurements were combined into one single measurement as a total plant height. Each root from a single plant was cut and root galls were counted. The average of the galls per root system was recorded.

\subsection{Statistical Analysis}

The data were analyzed using the JMP program version 10.0. (SAS). Data were subjected to analysis of variance (ANOVA) at significant levels $(\mathrm{P}<0.05)$ and means were compared with Each pair Student's t test.

\section{Results}

Typical symptoms of nematode attack are root knot formation called galls, a distinctive bulging of the roots, stunted growth, leaves losing chlorophyll, thinning plants, damage in patches, and premature wilting. (lsgouhi Kaloshian et al, 1995 ). The uprooted plants were examined for these symptoms.

\subsection{Nematode Control at $100^{\text {th }}$ Day}

At $100^{\text {th }}$ day, control plot plants had stunted growth and leaves appeared premature yellowing. Root examination showed root galls presence in all the roots. Chemically treated plants appeared with lesser symptoms compared to the control, but it had moderate galling in the roots. However, the shoots were less stunted and leaves showed little yellowing. Comparing the control, the chemically treated plants were better as indicated in the table 1; Figure $1 \& 2$. The plot that had Pseudomonas fluorescens application did not exhibit any nematode attack symptoms, except for few galls on the roots. The plants were healthier and had good vegetative growth and flowering. For all treatments, shoot height and root height were measured and recorded as total plant height. Nodules were counted for each root in the root bunch. Average nodules per plant root system were recorded. In comparison with control and chemical treated plots, Pseudomonas fluorescens treated plant showed significant increase in total plant height (table 1). Comparing chemically treated plants with control indicated chemically treated plants were less affected by the nematodes. Pseudomonas 
fluorescens treated plants were showing they were statistically different in all parameters from the other two treatments. (Table 1, Figure 1). Root gall count indicated control plant had higher average galls per plant root system compared to chemically treated plants, and Pseudomonas fluorescens treated plants (table 1). Pseudomonas fluorescens treated plants had lower root galls per root. Statistical analysis showed all three treatments were significantly different from one another at $100^{\text {th }}$ day from the nursery development (Table 1, Figure 2).

Table 1. Average plant height (shoot and root) of the tomato crop at $100^{\text {th }}$ from the nursery development.

\begin{tabular}{|c|c|c|c|c|c|c|c|}
\hline \multicolumn{8}{|c|}{ Treatments } \\
\hline \multirow[b]{2}{*}{ No } & \multirow[b]{2}{*}{ Fields } & \multicolumn{2}{|l|}{ Control } & \multicolumn{2}{|l|}{ Carbofuran } & \multicolumn{2}{|l|}{ Pseudomonas } \\
\hline & & Plant height & $\begin{array}{l}\text { Avgerage no of } \\
\text { galls/root }\end{array}$ & Plant height & $\begin{array}{l}\text { Avgerage no of } \\
\text { galls/root }\end{array}$ & Plant height & $\begin{array}{l}\text { Avgerage no of } \\
\text { galls/root }\end{array}$ \\
\hline 1 & Field A & 28 & 148 & 37 & 60 & 48 & 12 \\
\hline 2 & Field A & 23 & 108 & 31 & 73 & 41 & 10 \\
\hline 3 & Field A & 28 & 211 & 38 & 93 & 50 & 15 \\
\hline 4 & Field A & 21 & 175 & 33 & 65 & 51 & 18 \\
\hline 5 & Field A & 18 & 158 & 31 & 70 & 43 & 14 \\
\hline 6 & Field A & 24 & 194 & 39 & 56 & 46 & 12 \\
\hline 7 & Field A & 27 & 163 & 27 & 76 & 41 & 12 \\
\hline 8 & Field A & 23 & 149 & 30 & 65 & 44 & 18 \\
\hline 9 & Field A & 30 & 153 & 33 & 43 & 50 & 9 \\
\hline 10 & Field B & 36 & 147 & 35 & 52 & 38 & 11 \\
\hline 11 & Field B & 25 & 131 & 39 & 52 & 50 & 10 \\
\hline 12 & Field B & 24 & 182 & 37 & 57 & 55 & 17 \\
\hline 13 & Field B & 25 & 132 & 38 & 55 & 52 & 12 \\
\hline 14 & Field B & 27 & 163 & 32 & 63 & 58 & 15 \\
\hline 15 & Field B & 31 & 142 & 29 & 58 & 61 & 14 \\
\hline 16 & Field B & 35 & 174 & 33 & 56 & 42 & 14 \\
\hline 17 & Field B & 22 & 131 & 40 & 64 & 51 & 12 \\
\hline 18 & Field B & 26 & 145 & 36 & 59 & 48 & 16 \\
\hline 19 & Field B & 28 & 153 & 27 & 62 & 52 & 13 \\
\hline 20 & Field B & 21 & 127 & 20 & 55 & 47 & 10 \\
\hline
\end{tabular}

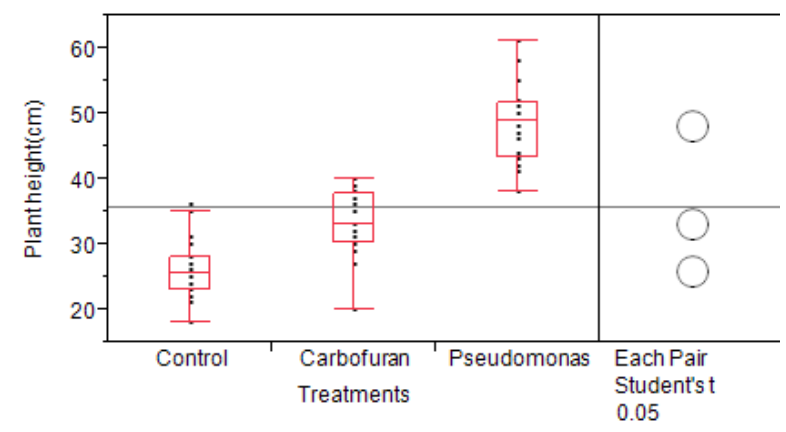

Figure 1. Influence of treatments on plant height at 100th day from the nursery development. Plant heights in $\mathrm{cm}$ are measured at 100th day from the nursery development. Data was analyzed using ANOVA and Student t test. Circles that do not overlap indicate the means are significantly different for $p$ value $(p<0.05)$

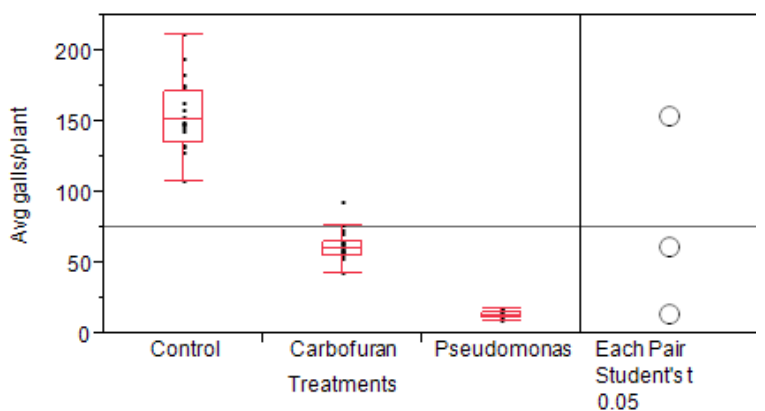

Figure 2. Influence of treatments on root gall formation at $100^{\text {th }}$ day from nursery development. Root galls are measured as an average of all roots in the plant. ANOVA and Student t test. Circles that do not overlap indicate the means are significantly different for $p$ value $(p<0.05)$

\subsection{Nematode Control at $160^{\text {th }}$ Day}

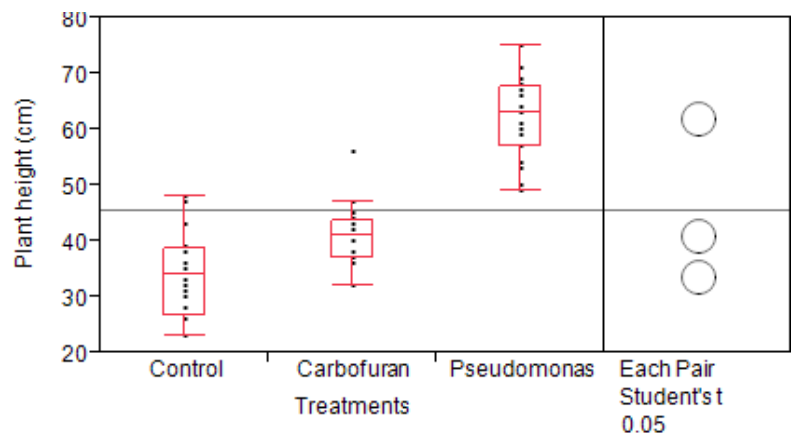

Figure 3. Influence of treatments on plant height at $160^{\text {th }}$ day from nursery development. Plant heights in $\mathrm{cm}$ are measured at $160^{\text {th }}$ day from the nursery development. Data was analyzed using ANOVA and Student t test. Circles that do not overlap indicate the means are significantly different for $p$ value $(p<0.05)$

Prior to uprooting the plants, they were visually inspected, and the symptoms were recorded. Both control and chemically treated plants exhibited severe symptoms of wilting and loss of growth. Plants in the control plot showed a complete damage by the nematode. They had little growth compared to the measurement made on the 100th day. The leaves showed wilting and no flowering. Chemically treated plants were moderately better than the control, but, still had significant loss of vegetative growth and flowering. Leaves exhibited strong wilting symptoms. 


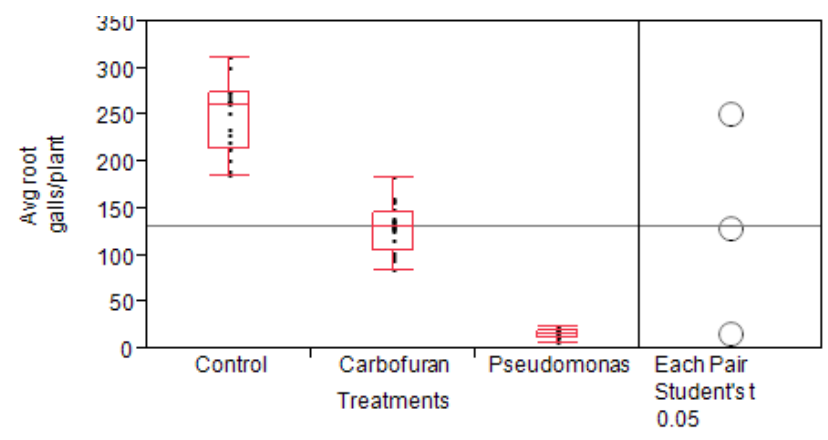

Figure 4. Influence of treatments on root gall formation at $160^{\text {th }}$ day from nursery development. Root galls are measured as an average of all roots in the plant. Data was analyzed using ANOVA and Student t test. Circles that do not overlap indicate the means are significantly different for $p$ value $(p<$ 0.05)

However, Pseudomonas fluorescens treated plants maintained its growth vigor, and flowering. For assessing the plant height, 10 plants from each plot were uprooted. Shoot and root height were measured for all the plants and were recorded as total plant height. Pseudomonas fluorescence treated plants were significantly better in terms of the shoot and root height. (Table 2). All three treatments showed significant difference in the means with p-value of less than 0.05 (Table 2, Figure 3).

Comparing root galls incidence, Pseudomonas treated plants had lower average galls compared to control and chemical treatments. Root gall count at the 160th day indicated control plant had higher average galls per root system followed by chemically treated plants. Pseudomonas fluorescens treated plants showed no significant increase in the root galls compared to $100^{\text {th }}$ day observation (Table 2) Statistical analysis indicated that all three treatments were significantly different from one another at $160^{\text {th }}$ day. $p$ value of less than alpha of 0.05 for all treatments showed the mean of the root galls were different from one another (Table 2, Figure 4).

Table 2. Average root galls per plant root system of the tomato crop at $100^{\text {th }}$ day from the nursery development

\begin{tabular}{|c|c|c|c|c|c|c|c|}
\hline \multicolumn{8}{|c|}{ Treatments } \\
\hline \multirow{2}{*}{ No } & & \multicolumn{2}{|l|}{ Control } & \multicolumn{2}{|l|}{ Carbofuran } & \multicolumn{2}{|l|}{ Pseudomonas } \\
\hline & & Plant height & $\begin{array}{l}\text { Avgerage no of } \\
\text { galls/root }\end{array}$ & Plant height & $\begin{array}{l}\text { Avgerage no of } \\
\text { galls/root }\end{array}$ & Plant height & Avgerage no of galls/root \\
\hline 1 & Field A & 33 & 261 & 40 & 134 & 68 & 20 \\
\hline 2 & Field A & 35 & 274 & 43 & 128 & 63 & 17 \\
\hline 3 & Field A & 39 & 263 & 56 & 115 & 69 & 21 \\
\hline 4 & Field A & 26 & 211 & 36 & 98 & 66 & 21 \\
\hline 5 & Field A & 23 & 273 & 37 & 155 & 59 & 16 \\
\hline 6 & Field A & 31 & 311 & 44 & 102 & 71 & 15 \\
\hline 7 & Field A & 38 & 200 & 37 & 160 & 57 & 11 \\
\hline 8 & Field A & 36 & 184 & 32 & 137 & 60 & 23 \\
\hline 9 & Field A & 35 & 227 & 38 & 83 & 61 & 12 \\
\hline 10 & Field B & 48 & 262 & 40 & 93 & 49 & 16 \\
\hline 11 & Field B & 39 & 311 & 42 & 131 & 66 & 20 \\
\hline 12 & Field B & 26 & 233 & 32 & 182 & 54 & 17 \\
\hline 13 & Field B & 23 & 189 & 43 & 127 & 68 & 12 \\
\hline 14 & Field B & 47 & 219 & 45 & 124 & 57 & 18 \\
\hline 15 & Field B & 32 & 312 & 47 & 135 & 75 & 11 \\
\hline 16 & Field B & 43 & 269 & 47 & 83 & 64 & 15 \\
\hline 17 & Field B & 26 & 264 & 42 & 158 & 63 & 9 \\
\hline 18 & Field B & 30 & 251 & 37 & 129 & 67 & 15 \\
\hline 19 & Field B & 28 & 300 & 43 & 148 & 50 & 5 \\
\hline 20 & Field B & 36 & 213 & 38 & 139 & 53 & 15 \\
\hline
\end{tabular}

\section{Discussion}

Among all three treatments, Pseudomonas fluorescens had better resistance to nematode attack. In all three plots, seedlings were able to establish themselves. Once nematodes sensed the root exudates, they migrate to the plant rhizosphere. The signals stimulate egg hatch, attraction to target tissues (Zhao X et al, 2000). Previous studies have identified root exudates even from a single root could alter the behavior of the nematodes (Griffin D M et al, 1972). As the results indicate, nematode attack took place within a few days after transplantation in the control plots. Nematode infestation is based on biochemical substance present within the root surface and the rhizosphere (Pierson L S, 2000). Since control plants have the natural biochemical signal that favors the nematode mobility and infestation to its root 
system. $M$. incognita undergoes a reversible change in the motility that helps in its migration, and the existing favorable conditions help nematodes to enter the root system and reach the vascular system (Bird A F, 1959). On entering the root system, the mode of pathological action includes blocking the nutrient, and water availability for plants (Sikora RA, 1988). In chemically treated plots, soil rhizosphere undergoes changes, which makes nematode immobile. A general concept of the chemical action on the nematode is that acetyl cholinesterase enzyme is inhibited, causing the nematode to undergo physiological and behavioral effects that incapacitates the nematodes PerryD J et al, (1990). Although these changes are reversible, and nonlethal as indicated in previous research that had shown the effects of toxicology of the carbamate reduced and were reversible in the nematodes. This study reiterates previous findings. Assessing the plant symptoms at $100^{\text {th }}$ day and $160^{\text {th }}$ day clearly shows the progression of the symptoms after $100^{\text {th }}$ day. Chemically treated plants were similar to untreated plants at the $160^{\text {th }}$ day. They had extensive symptoms, including loss of growth, leaves and almost no flowering.

Analyzing the results for the Pseudomonas fluorescens treated plots showed that the bacteria were able to establish and increase the population in the rhizosphere. Bacteria then colonize the chilli roots Yeole R D et al, (2001) within few days after transplanting. Fewer root galls were seen in the Pseudomonas fluorescens treated plants. However, comparing $100^{\text {th }}$ day and $160^{\text {th }}$ day, there was no progression of the root galls as seen in the chemically treated plants. This clearly indicates the efficacy of Pseudomonas fluorescens in preventing the nematode entry into the root system. Also, these plants exhibited progressive growth and flowering. Examining the roots, showed fewer root nodules. Bacteria were able to establish a symbiotic relationship with the plant root system. A favorable environment exists, where nutrients released by the plant in the form of root exudates are available to the Pseudomonas to establish and increase its population. The root colonization creates a protective layer against nematodes (Bull CT, 1991).

Plant Growth Promoting Substance (PGPR) compounds, including Hydrogen Cyanide (HCN), and other scavenging compounds (Kloeppe J W, and Rodriguez-Kabana R, 1999) was identified as factor for antagonistic activity. Microorganisms in the rhizosphere interact either symbiotically or antagonistically. Earlier studies had identified and enumerated the mechanisms of controlling pathogens, including nematodes (Nandakumar R et al, 2001). Among the mechanisms that are more effective and studied extensively are productions of cell wall lytic enzymes, exuding certain polysaccharides like lipopolysaccharide or salicylic acid (Singh P P et al, 1999, Van Peer R and Schippers B, 1992.), which reduce the mobility of the nematodes (Robin Duponnois and Amadou M, 1998). Other well characterized factors are ISR induced by Pseudomonas fluorescens, which resulted in increased activity of PO, PPO, PAL and phenol. This provides universal events that lead to preventing nematode attack. Kandan A et al, (2002). Pfl are the best inducers of plant chitinase and peroxidase, which is crucial for ISR Nandakumar R et al, (2000) against nematode attack (Anita E and Rajendran G, 2002). The study as reported showed the efficiency of the biocontrol in controlling the nematode infestation in the chile crop.

\section{Conclusion}

The study concludes Pseudomonas fluorescens as an efficient biocontrol for nematode management in the chilli crops and also, it clearly indicates that biocontrol were more effective in providing a prolonged nematode attack resistance to the chilli crops compared to the chemical Carbofuran. With the reversible nature of the chemicals, crop protection was not sustainable as compared to biological control. Developing and further characterizing more beneficial microorganisms will in future provide a comprehensive crop protection.

\section{Acknowledgements}

The authors acknowledge the help of Dana R Broussard for improving the manuscript.

\section{References}

[1] Bird A.F, "The Inducement of Giant Cells by Meloidogyne Javanica," Nematologica, vol. 8, pp. 8-10, 1960.

[2] Bird. A.F, "Changes associated with parasitism in nematodes. IV. Cytochemical studies on the ampulla of the dorsal esophageal gland of Meloidogyne javanica and on exudations from the buccal stylet." J. Parasitol., vol. 54, pp. 879-890, 1968 .

[3] Alam M.M., Siddiqi Z.A., Khan A.M., Saxena S.K., "Effect of different crop sequences on the population of plant para $\neg$ sitic nematodes.," . Indian J. Nematol., vol. 10(1), pp. 35-39, 1980.

[4] Van Peer, R. and B. Schippers., "Lipopolysaccharides of plant growth-promoting Pseudomonas sp. strain WCS417r induce resistance in carnation to Fusarium wilt. Neth.," Plant Pathol., vol. 98, pp. 129-139, 1992.

[5] Becker, J. O., E. Zavaleta-Mejia, S. F. Colbert, M. N. Schroth, A. R. Weinhold, J.G. Hancock, and S. D. Van Gundy.. Effects of rhizobacteria on root-knot nematodes and gall formation. Phytopathology 78:1466-1469, 1988

[6] A.F. Bird, "The attractiveness of roots to the plant parasitic nematodes Meloidogyne javanica and M. hapla," Nematologica, vol. 4, pp. 322-335, 1959.

[7] A. F. Bird., "Inducement of Giant Cells by Meloidogyne Javanica,” Nematologica, vol. 1962, pp. 1-10, 1962.

[8] Kerry. B.R, "Rhizosphere interactions and the exploitation of microbial agents for the biological control of plant-parasitic nematodes," Phytopathology, vol. 38, pp. 423-441, 2000.

[9] CT Bull, DM Weller, LS Thomas, "How relationship between root colonization and suppression of Gaeumannomyces graminis var. tritici by Pseudomonas fluorescens strain," Phytopathology, vol. 81, pp. 954-959, 1991. 
[10] Keel. CJ, "Bacterial antagonists of plant pathogens in the rhizosphere: Mechanisms and prospects," OIL/SROP, vol. xv, pp. 93-99, 1992.

[11] D.J. PREE, J. L. TOWNSHEND, AND K. J. COLE, "Inhibition of Acetylcholinesterases from Aphelenchus avenae by Carbofuran and Fenamiphos," J. Phytopathol., vol. 22(2), pp. 182-186, 1990.

[12] Jonathan E. I, K. R. Barker, F. F. Abdel-Alim, T. C. Vrain, and D W. Dickson, "Biological control of Meloidogyne incognita on tomato and banana with rhizobacteria, actinomycetes, and Pasteuria penetrans.,"Nematropica, vol. 30, pp. 231-240, 2000.

[13] Nordmeyer D. and Dickson DW., "Effect of carbamate, organophosphate and Avermectin nematicides on oxygen consumption by three Meloidogyne spp.," nematology, vol. 21(4), pp. 472-476, 1989.

[14] Anita E and Rajendran G, "Nursery application of Pseudomonas fluorescens for the control of meloidogyne incognita on tomato and brinjal," Nematol. Mediterr., vol. 30, pp. 209-210, 2002.

[15] Duffy, B. K., and Défago, "Zinc improves biocontrol of Fusarium crown and root rot of tomato by Pseudomonas fluorescens and represses the production of pathogen metabolites inhibitory to bacterial antibiotic biosynthesis," Phytopathology, vol. 87, pp. 1250-1257, 1997.

[16] F. Griffin, D. M., Hale, M. G., and Shay, "Nature and quantity of sloughed organic matter produced by roots of axenic peanut plants," SOIL BIOL.BIOCHEM, vol. 8, pp. 29-32, 1976.

[17] Gamliel, A., and J. Katan, "Involvement of fluorescent pseudomonads and other microorganisms in increased growth response of plants in solarized soils," Phytopathology, vol. 81, pp. 494-502, 1991.

[18] Giebel. J, "Biochemical mechanisms of plant resistance to nematodes," Nematologica, pp. 175-181, 1974.

[19] Schroth, M. N. and Hancock, J. G..., "Disease-suppressive soil and root-colonizing bacteria." Science (80-. )., vol. 216, pp. 1376-1381, 1982.

[20] D. D. Jonathan EI, Barker KR, Abdel-Alim FF, Vrain TC, "Biological control of Meloidogyne incognita on tomato and banana with rhizobacteria, actinomycetes, and Pasteuria penetrans," Nematropica, vol. 30, pp. 231-240, 2000

[21] S. R. Kandan A, Radjacommare R, Nandakumar R, Raguchander T, Ramiah M, "Induction of phenylpropanoid metabolism by Pseudomonas fluorescens against tomato spotted wilt virus in tomato," F MICROBIOL, vol. 47, pp. 121-129, 2002.

[22] L. B. Kloeppe DA, Nyczepir AP, Lawrence JE, "Biological Control of the Phytoparasitic Nematode Mesocriconema xenoplax on Peach Trees," nematology, vol. 34(2), pp. 120 $123,2002$.

[23] Barker. KR, "Nematode extraction and bioassays," Methodology, vol. 2, pp. 4-5, 1985.

[24] Raguchander. T. and S. R. Nandakumar R, Babu S, Viswanathan R, "Induction of systemic resistance in rice against sheath blight disease by Pseudomonas fluorescens," SOIL BIOL.BIOCHEM, vol. 33(4), pp. 603-612, 2000.

[25] Sheela. J. Raguchander. T. and Samiyappan. R. Nandakumar R, Babu S, Viswanathan S, "A new bio-formulation containing plant growth promoting rhizobacterial mixture for the management of sheath blight and enhanced grain yield in rice," BIOCONTROL, vol. 46, pp. 493-510, 2001.

[26] Nusbaum C.J., Ferris H., "The role of cropping systems in nematode population management.," Ann. Rev. Phytopa $\neg$ thology, vol. 11, pp. 423-440, 1973.

[27] L. S. Pierson., ". Expanding the club: engineering plants to talk to bacteria.,". Trends Plant Sci., vol. 5, pp. 89-91, 2000.

[28] JW Kloeppes ., R Rodriguez-Kabana., "Plant root-bacterial interactions in biological control of soil borne diseases and potential extension to systemic and foliar diseases," Australas. Pathol., vol. 28, pp. 21-26, 1999.

[29] Sikora. RA., "Interrelationship between plant health promoting rhizobacteria, plant parasitic nematodes and soil microorganisms.," . Meded. Fac. Landb, Rijksuniv Gen, vol. 53, pp. 867-878, 1988.

[30] Cook. RJ, "Making greater use of introduced microorganisms for biological control of plant pathogens.," Phytopathology, vol. 31, pp. 53-80, 1993.

[31] Hussey. RS, "Disease-inducing secretions of plant-parasitic nematodes.," Annu. Rev. Phytopathol., vol. 27, pp. 123-141, 1989.

[32] 1. Siddiqui IA and Ehteshamul-Haque S, "Use of Pseudomonas fluorescens aeruginosa for the control of root rot-root knot disease complex in tomato," Plant soil, vol. 227, pp. 163-169, 2000.

[33] Robin Duponnois., Amadou M. BA and Thierry Mateille., " Effects of sorne rhizosphere bacteria for the biocontrol of nematodes of the genus, Meloidogyne with Arthrobotrys oligospora," fF A Nemawl, vol. 21(2), pp. 157-163, 1998.

[34] Sitaramaiah K.,. Plant Parasitic Nematodes of India. Today and Tomorrow. Printers and Publishers, New Delhi: 292, 1984

[35] M. I. Siddiqui ZA, "Role of bacteria in the management of plant parasitic nematodes: Bioresource technology.," A Rev., 69AD.

[36] Singh, P.P, Y.C. Shin, C.S. Park and Y.R. Chung," "Biological control of Fusarium wilts of cucumber by chitinolytic bacteria.," Phytopathology, vol. 89, no. 92-99, 1999.

[37] J. Handlesman and E. V. Stabb, "Biocontrol of Soil borne Plant Pathogens," Plant Cell, vol. 8, pp. 1855-1869, 1966.

[38] Nandakumar R, Babu S, Viswanathan R, Raguchander T and Samiyappan R. Induction of systemic resistance in rice against sheath blight disease by Pseudomonas fluorescens. Soil Biol. Biochem 33 (4), 603-612, 2000.

[39] Vidhyasekaran, P., R. Rabindran, M. Muthamilan, K. Nayar, K. Rajappan, N. Subramanian and K. Vasumathi, "Development of powder formulation of Pseudomonas fluorescens for control of rice blast.," Plant Pathol., vol. 46, pp. 291-297, 1997.

[40] 1sgouhi Kaloshian Valerie M. Williamson Gene Miyao Dennis A. Lawn Becky Westerdahl, "Resistance-breaking nematodes identified in California tomatoes," Calif. Agric., vol. 50, pp. 6-7, 1995.

[41] Windhum GL, Windhum MT \& Williams WP, "Plant Effect of Trichoderma species on maize growth and Meloidogyne," pp. 701-15, 1989. 
[42] H. C. D. Yeole, R. D., B. P. Dave, "'Siderophore production by fluorescent pseudomonads colonizing roots of certain crop plants.,"”." Indian J. Exp. Biol., vol. 39, pp. 464-468, 2001.

[43] M. C. Zhao, X., Schmitt, M., and Hawes, "Species-dependent effects of border cell and root tip exudates on nematode behavior," Phytopathology, vol. 90, pp. 1239-1245, 2000.

[44] R. Nandakumar, S. Babu, R. Viswanathan, J. Sheela T. Raguchander And R. Samiyappan A new bio-formulation containing plant growth promoting rhizobacterial mixture for the management of sheath blight and enhanced grain yield in rice, BioControl 46: 493-510, 2001.
[45] J Giebel, Biochemical mechanisms of plant resistance to nematodes: A review, - Journal of nematology, 1974

[46] Samaraj S. Thiyagarajan, and K. Hari, Tomato Root Knot Nematode Control through Biocontrol Agent Pseudomonas fluorescens. International Journal of Research in Agricultural Sciences, Volume 1, Issue 4, ISSN(Online):2348-3997, 2014. 